\title{
Perasaan Bersalah Pada Mantan Pengguna Narkoba
}

\section{Guilty Feelings of Former Drug Users}

\author{
M. Ikhsan Fanani Nuruddin ${ }^{1 *}$, Achmad Dandi Firmansyah ${ }^{1}$, Safira Kusnaini ${ }^{1}$, Arika Maulidia ${ }^{1}$, Novia \\ Dinda $^{1}$, Titin Ringgiani Kumala Dewi ${ }^{1}$, dan Suryani ${ }^{1}$ \\ ${ }^{1}$ Fakultas Psikologi dan Kesehatan, Universitas Islam Negeri Ampel Surabaya \\ *mikhsanfananin@gmail.com
}

\begin{abstract}
Abstrak
Penelitian ini bertujuan untuk menggambarkan rasa bersalah mantan pengguna narkoba. Penelitian ini merupakan penelitian kualitatif menggunakan metode studi kasus. Subjek dalam penelitian ini adalah empat orang mantan pengguna narkoba. Data penelitian diperoleh melalui wawancara dan observasi. Hasil dari penelitian ini menunujukkan gambaran rasa bersalah yang berbeda pada masing-masing subjek di antaranya adalah: 1) subjek pertama merasa tertekan; 2) subjek kedua meminta maaf kepada orang terdekat hingga menyalahkan diri sendiri; 3) subjek ketiga menarik diri dari lingkungan; dan 4) subjek keempat lebih mendekatkan diri kepada Tuhan. Berdasarkan hal tersebut perasaan bersalah dapat timbul dalam berbagai bentuk pada mantan pengguna narkoba.
\end{abstract}

Kata kunci: perasaan bersalah, pengguna narkoba, remaja

\begin{abstract}
This study aims to describe guilty feelings of former drug users. This research is a qualitative research using the case study method. The subjects in this study were four former drug users. The research data were obtained using interviews and observations. The result of this study show a different description of guilty feelings in each subject: 1) The first subject feels depressed; 2) The second subject apologized to the closest person and blame herself; 3) The third subject had been withdrawn; And 4) The fourth subject is being more closer to God.
\end{abstract}

Keywords: guilty feelings, drug users, adolescents

\section{Pendahuluan}

Fenomena yang terjadi di lingkungan masyarakat berkaitan dengan perilaku menyimpang semakin merebak akhir-akhir ini, terlebih terkait dengan penyalahgunaan narkotika, psikotropika, dan obat terlarang, yang disingkat dengan narkoba. Dilansir dari laman resmi milik Badan Narkotika Nasional (BNN) dalam World Drugs Reports 2018 yang diterbitkan oleh United Nations Office on Drugs and Crime (UNODC) mencatat sebanyak 275 juta penduduk dunia yang berusia sekitar 15-64 tahun pernah mengonsumsi narkoba. Sementara di Indonesia, BNN menyebutkan sebanyak lebih dari 3 juta orang pada rentang usia 10-59 tahun terlibat aktivitas penyalahgunaan narkoba pada tahun 2017. Lebih jauh, angka penyalahgunaan Narkoba di kalangan pelajar di tahun 2018 (dari 13 ibukota provinsi di Indonesia) mencapai angka 2,29 juta orang. Adapun para generasi milenial yang berada pada rentang usia 15-35 tahun termasuk dalam golongan yang rawan terpapar penyalahgunaan narkoba (BNN, 2019). Hal ini menunjukkan bahwa remaja juga turut menjadi pengguna narkoba.

Menurut Syifaunnufush dan Diana (2017), penggunaan narkoba di usia remaja merupakan bagian dari fenomena kenakalan remaja. Dalam hal ini terjadi pergeseran di mana sebelumnya fenomena penyimpangan perilaku remaja berupa mencontek, membolos, merokok, dan tidak patuh pada orangtua, kini telah beralih menjadi perilaku kriminalitas seperti tawuran, minum-minuman keras, hingga penggunaan narkoba. Lebih jauh Sumara, Humaedi, \& Santoso (2017) berpendapat bahwa kenakalan 
remaja merupakan bagian dari kerusakan moral. Dalam hal ini kenakalan remaja meliputi semua perilaku yang menyimpang dari norma-norma hukum pidana dan dapat merugikan dirinya sendiri serta lingkungan sekitar.

Berdasarkan hasil penelitian (Nurmaya, 2016) penggunaan narkoba di kalangan remaja dapat terjadi karena faktor lingkungan pergaulan atau teman sebaya. Hal ini tentunya berkaitan dengan fase perkembangan masa remaja, di mana salah satu tugas perkembangan masa remaja adalah bergaul dengan teman sebaya (William Kay, dalam Jahja, 2011). Masa remaja yang juga disebut sebagai masa peralihan dari anak-anak menuju dewasa membuat remaja megalami kebingungan. Dalam hal ini, terjadi keraguan akan peran yang harus dilakukan oleh remaja tersebut (Hurlock, 1997).

Pada masa remaja, individu sering dikaitkan dengan eksplorasi identitas. Di dalam proses eksplorasi, remaja berusaha mencari dan menemukan apa saja yang cocok bagi diri remaja, baik dari segi karir, percintaan, agama, hingga politik (Newman \& Newman, 2012). Dalam hal ini remaja berupaya untuk mengembangkan identitasnya dengan menyelesaikan tugas-tugas perkembangannya. Keberhasilan remaja dalam melaksanakan tugas-tugas perkembanyannya akan mulai memahami siapakah dirinya dan apa yang seharusnya dilakukan, dengan begitu remaja dapat membawa kesuksesan dalam pelaksanaan tugas perkembangan selanjutnya. (Al-Mighwar, 2011; dalam Syifaunnufush \& Diana, 2017). Sebaliknya ketika remaja gagal mengembangkan identitasnya, maka remaja akan mengalami krisis identitas. Krisis identitas merupakan suatu titik balik yaitu ketika remaja merasakan kerentanan tetapi di sisi lain kemampuannya menguat (Erikson, 1989). Keadaan krisis identitas ditandai dengan kebingungan remaja terhadap identitas dirinya, penyangkalan peran berupa kurangnya rasa percaya diri, serta perilaku menyimpang atau memberontak (Feist \& Feist, 2010).

Hal serupa juga disebutkan oleh Erikson bahwa kebingungan peran dapat membuat remaja menarik diri (self-withdrawl) dari lingkungan sosialnya dan berperilaku menyimpang (delinquent) sehingga dapat membuat remaja memiliki identitas diri yang negatif. Lebih jauh, kebingungan peran menimbulkan perasaan hilang arah, perasaan bersalah, perasaan takut, dan perasaan gagal dalam mencapai nilai-nilai yang ada di lingkungan tempat tinggalnya (Dacey, 1982; dalam Pratiwi, 2018). Berdasarkan hal tersebut, dapat dikatakan bahwa selama proses eksplorasi identitas remaja dapat berperilaku meyimpang, tidak terkecuali para pengguna narkoba, yang pada akhirnya akan menimbulkan perasaan bersalah pada dirinya.

Rasa bersalah didefinisikan sebagai emosi berbasis agitasi untuk menyesali tindakan atau keputusan yang salah (Ferguson dan Stegge, 1998). Berdasarkan definisi ini, pengguna narkoba melihat aspek perbuatan salah dari tindakan atau keputusanya, memikul tanggung jawab, dan keinginan untuk menemukan cara untuk membatalkan kesalahan atau menghukum diri sendiri (Eisenberg 2000). Berdasarkan hal tersebut, orang yang dilanda rasa bersalah tertarik untuk mempertimbangkan perilaku atau tindakan dan konsekuensinya, daripada merasa terdorong untuk membela diri. Ketika merasa bersalah, orang cenderung merenungkan kesalahan dan berharap berperilaku berbeda.

Menurut Cohen, Wolf, Panter, \& Insko (2011) kecenderungan merasa bersalah memiliki dua karakteristik khusus yaitu, evaluasi perilaku negatif dan memperbaiki tindakan. Evaluasi perilaku negatif, di mana pengguna narkoba mampu menyadari dan mengevaluasi terhadap tindakan atau perbuatan yang menurutnya salah seperti, “'aku telah melakukan kesalahan"” sedangkan memperbaiki suatu tindakan yang salah seperti. "meminta maaf". Cohen, dkk (2011) berpendapat bahwa rasa bersalah berhubungan secara positif dan signifikan dengan religiusitas dan moral. Moral mencakup perasaan bersalah dan perasaan menyesal yang digambarkan sebagai ketidaknyamanan setelah melakukan perilaku yang menyimpang.

Dimensi rasa bersalah menurut Jurnal Mental Illness Of Victoria (2008) dapat digambarkan sebagai berikut: a) Merasa tanggung jawab terhadap keadaan negatif yang telah terjadi pada dirinya dan orang lain; b) Merasa menyesal untuk kelakuan buruk, baik yang nyata maupun yang dibayangan, di masa lalu maupun sekarang; c) Perasaan menyesal yang sangat dalam dari pemikiran, perasaan atau sikap yang bersifat mencela dan tidak menerima tentang diri sendiri atau orang lain; d) Merasa berhutang karena tidak menyenangkan, tidak menolong, atau tidak menentramkan seseorang; e) Merasa bingung dan kurang seimbang karena tidak merespon terhadap suatu situsi dengan tata krama biasa; f) Merasa kehilangan dan malu karena tidak melakukan atau berkata sesuatu kepada seseorang yang sudah tidak bersama; g) Menerima tanggung jawab atas kemalangan atau masalah orang lain dikarenakan ketidakmampuan melihat orang tersebut menderita; h) Memotivasi untuk mengubah kesalahankesalahan yang pernah diperbuat atau dipersepsikan; i) Memiliki perasaan moral yang kuat akan kesalahan dan kebenaran, yang mana menghalangi untuk memilih bagian kesalahan dari suatu tindakan; j) Berperilaku dengan terpaksa atau bersembunyi yang mana tersembunyi kepercayaan yang irasional. 
Coleman (1985) menyebutkan terdapat beberapa akibat yang ditimbulkan dari rasa bersalah yakni: a) Merasa rendah diri. Rasa salah tidak hanya melahirkan rasa rendah diri, rasa tidak aman, dan rasa malu, merasa kacau, rasa takut, rasa salah bisa jadi sumber berkembangnya persoalan emosional seperti kasihan diri; b) Gangguan fisik yang dapat ditimbulkan. Stres berhubungan dengan penyakit fisik maka rasa salah harus selalu dianggap sebagai sumber utama stres mental. Dapat ditambahkan bahwa perasaan bersalah seperti kelelahan dan tidak enak badan pun biasanya dihubungkan dengan gangguan pikiran; c) Hal-hal yang baik. Rasa salah serta rasa takut yang berkaitan dengan rasa salah sehingga membuat jujur, berhati-hati, salah satu yang membuat lebih cermat, bermoral, baik hati, murah hati, ambisius, berkerja keras, kreatif, paling adil, dan paling penuh perhatian, mentaati hukum, rasa sesal.

Berdasarkan hal tersebut, penelitian ini bertujuan untuk mengetahui bentuk perasaan bersalah pada mantan pengguna narkoba.

\section{Metode Penelitian}

Penelitian ini menggunakan pendekatan kualitatif guna mendapatkan gambaran serta informasi yang mendalam terkait perasaan bersalah pada mantan pengguna narkoba. Adapun metode yang digunakan dalam penelitian ini adalah studi kasus. Sedangkan Teknik pengumpulan data dilakukan dengan wawancara secara mendalam (indepth interview). Wawancara dilakukan secara langsung terhadap mantan pengguna narkoba guna menjaga keakuratan data yang diperoleh serta untuk menjaga kerahasiaan subjek. Subjek dalam penelitian ini sebanyak empat orang mantan pengguna narkoba yang terdiri dari dua laki-laki dan dua perempuan. Lama penggunaan narkoba oleh keempat subjek bervariasi, dari mulai satu hingga delapan tahun. Saat ini rata-rata subjek berhenti menggunakan narkoba sejak 12 tahun lalu.

\section{Hasil Penelitian}

Berdasarkan hasil wawancara terhadap subjek diketahui bahwa tiga dari empat orang mengenal obat-obatan terlarang atau narkoba sejak duduk di bangku sekolah, subjek mulai mengenal dan menggunakan narkoba saat berusia sekitar 12 tahun atau sekitar kelas 6 dan awal masuk SMP. Sedangkan satu subjek yang lainnya mengenal narkoba ketika subjek memasuki dunia perkuliahan. Adapun subjek mengetahui barang-barang tersebut dari orang-orang terdekat seperti teman dan saudaranya. Saat ini keempat subjek sudah tidak lagi menggunakan narkoba. Hal ini dikarenakan alasan yang berbeda-beda. Salah satu subjek mengaku bahwa ingin lepas dari narkoba dikarenakan ingin berubah menjadi lebih baik. Di samping itu juga karena permasalahan ekonomi yang memaksa dirinya untuk tidak lagi mengonsumsi narkoba dari dampak yang dirasakan adalah kehabisan harta, menjadi boros, dan lain-lain. Hal serupa juga dialami oleh subjek kedua yang mengaku semakin boros ketika menjadi pengguna narkoba.

Subjek pun mengalami perubahan perilaku akibat penggunaan narkoba, seperti menjadi semakin malas dan mengalami kemunduran dalam aktivitas perkuliahan. Kemudian kesehatan mereka pun mengalami masalah, seperti merasakan pusing yang berlebihan, sistem imun menurun, nafsu makan menurun, merasakan sesak nafas dan lain sebagainya. Sedangkan dampak psikologis yang dirasakan subjek bermacam-macam, di antaranya merasa cemas, kurang bisa tidur hingga menyebabkan insomnia, menjadi kurang konsentrasi dalam beraktivitas, merasa berdosa, merasa bahwa masa depannya suram, hingga menjadi malas dalam melakukan kegiatan sehari-hari. Oleh sebab itu, subjek ingin berubah menjadi lebih baik lagi dengan meninggalkan lingkungan bergaulnya, serta berusaha berhemat untuk dapat bertahan hidup di tanah rantau.

Secara umum keempat subjek mengaku bahwa yang memotivasi mereka adalah ingin berusaha menjadi pribadi yang lebih baik lagi. Jika dilihat dari sisi perasaan bersalah, setiap subjek memiliki kisah yang hampir serupa. Subjek merasa menyesal karena merasa tidak ada manfaatnya dan justru merusak tubuhnya. Hal yang sama juga terjadi pada subjek lainnya yang mengaku menyesal telah menggunakan narkoba karena hal tersebut membuat badannya menjadi sakit-sakitan. Subjek juga mengaku bahwa perilakunya menjadi semakin buruk, di mana subjek sampai rela melakukan tindakan pencurian, taruhan, berjudi, hingga membunuh seseorang akibat pengaruh narkoba dan minuman keras. Sedangkan pada dua subjek lainya mengaku bahwa meskipun sempat memiliki perasaan menyesal atau bersalah, saat ini mereka sudah bisa menerima masa lalu dan bersyukur telah berhasil melaluinya dan terlepas dari narkoba. 
Berikut merupakan gambaran singkat terkait hasil penelitian yang diperoleh dari wawancara dengan mantan pengguna narkoba yang tertera pada Tabel.1 Hasil wawancara subjek terkait bentuk rasa bersalah dan dampak penggunaan narkoba.

Tabel 1. Hasil wawancara subjek terkait bentuk rasa bersalah dan dampak penggunaan narkoba

\begin{tabular}{|c|c|c|c|c|c|}
\hline \multirow{2}{*}{ No } & \multirow{2}{*}{ Subjek } & \multirow{2}{*}{$\begin{array}{c}\text { Bentuk Rasa } \\
\text { Bersalah }\end{array}$} & \multicolumn{3}{|c|}{ Dampak } \\
\hline & & & Psikologis & Ekonomi & Kesehatan \\
\hline 1 & Pertama & $\begin{array}{l}\text { Merasa } \\
\text { tertekan, }\end{array}$ & $\begin{array}{l}\text { 1. Merasa cemas } \\
\text { 2. Merasa susah } \\
\text { tidur yang } \\
\text { menyebabkan } \\
\text { Insomnia } \\
\text { 3. Menjadi } \\
\text { Paranoid }\end{array}$ & $\begin{array}{l}\text { 1. Perekonomian } \\
\text { keluarga } \\
\text { menjadi } \\
\text { menurun }\end{array}$ & $\begin{array}{l}\text { 1. Nafsu makan } \\
\text { menjadi } \\
\text { berkurang } \\
\text { 2. Merasa Pusing }\end{array}$ \\
\hline 2 & Kedua & $\begin{array}{l}\text { Meminta } \\
\text { maaf, } \\
\text { menyalahkan } \\
\text { diri sediri }\end{array}$ & $\begin{array}{l}\text { 1. Merasa kurang } \\
\text { konsentrasi } \\
\text { saat } \\
\text { melakukan } \\
\text { sesuatu }\end{array}$ & $\begin{array}{l}\text { 1. Menghabiskan } \\
\text { banyak uang } \\
\text { 2. Cenderung } \\
\text { meminjam } \\
\text { uang }\end{array}$ & $\begin{array}{l}\text { 1. Paru-paru } \\
\text { menjadi rusak } \\
\text { 2. Jerawat sering } \\
\text { muncul } \\
\text { 3. Menstruasi } \\
\text { menjadi tidak } \\
\text { lancar }\end{array}$ \\
\hline 3 & Ketiga & $\begin{array}{l}\text { Menarik diri } \\
\text { dari } \\
\text { lingkungan } \\
\text { sekitar }\end{array}$ & $\begin{array}{l}\text { 1. Merasa } \\
\text { berdosa } \\
\text { 2. Merasa bahwa } \\
\text { masa } \\
\text { depannya } \\
\text { suram }\end{array}$ & $\begin{array}{l}\text { 1. Cenderung } \\
\text { suka mencuri } \\
\text { dan mencopet } \\
\text { 2. Menghabiskan } \\
\text { harta dan } \\
\text { benda }\end{array}$ & $\begin{array}{l}\text { 1. Menambah } \\
\text { energi di awal } \\
\text { penggunaan } \\
\text { 2. Badan mudah } \\
\text { terserang } \\
\text { penyakit } \\
\text { 3. Menjadi Sakau }\end{array}$ \\
\hline 4 & Keempat & $\begin{array}{l}\text { Lebih } \\
\text { mendekatkan } \\
\text { diri pada } \\
\text { Tuhan. }\end{array}$ & $\begin{array}{l}\text { 1. Merasa kurang } \\
\text { konsentrasi } \\
\text { 2. Merasa malas } \\
\text { melakukan } \\
\text { kegiatan } \\
\text { sehari-hari } \\
\end{array}$ & 1. Menjadi boros & $\begin{array}{l}\text { 1. Menjadi Sesak } \\
\text { nafas } \\
\text { 2. Menambah } \\
\text { energi di awal } \\
\text { penggunaan }\end{array}$ \\
\hline
\end{tabular}

\section{Pembahasan}

Dari hasil penelitian di atas menunjukkan beberapa dampak yang ditimbulkan dari mengonsumsi narkoba yaitu: dari sisi psiklogis seperti merasa cemas, merasa susah tidur yang menyebabkan insomnia hingga menjadi paranoid. Sedangkan dari segi ekonomi subjek menjadi suka mencuri, suka mencopet, hingga menghabiskan harta dan benda, serta perekonomian keluarga menjadi menurun. Di sisi lain dampak kesehatan dapat menyebabkan nafsu makan menjadi menurun, merasa pusing, mengalami kerusakan pada organ paru-paru, jerawat sering muncul, juga pada wanita dapat menyebabkan menstruasi menjadi tidak lancar. Selain itu juga ditemukan bentuk dari rasa bersalah pada keempat subjek adalah merasa tertekan, meminta maaf kepada orang-orang yang dirugikan, menyalahkan diri sediri, menarik diri dari lingkungan sekitar dan lebih mendekatkan diri pada penciptaNya.

Berdasarkan hal tersebut, Coleman (1985) menyebutkan terdapat beberapa akibat yang ditimbulkan dari rasa bersalah: Pertama, merasa rendah diri. Rasa salah tidak hanya melahirkan rasa rendah diri, rasa tidak aman, rasa malu, merasa kacau, rasa takut, melainkan rasa salah bisa jadi sumber berkembangnya persoalan emosional seperti kasihan diri. Kedua, gangguan fisik yang dapat ditimbulkan. Stres berhubungan dengan penyakit fisik maka rasa salah harus selalu dianggap sebagai sumber utama stres mental. Dapat ditambahkan bahwa perasaan bersalah seperti kelelahan dan tidak enak badan pun biasanya dihubungkan dengan gangguan pikiran. Ketiga, hal-hal yang baik. Rasa salah serta rasa takut yang berkaitan dengan rasa salah sehingga membuat seseorang jujur, berhati-hati, menjadikan diri lebih cermat, bermoral, baik hati, murah hati, ambisius, berkerja keras, kreatif, paling adil, dan paling penuh perhatian, serta menaati hukum. 
Hal tersebut sebagaimana yang terjadi kepada masing-masing subjek, di mana pada subjek pertama yang mengalami paranoid. Pada beberapa subjek yang lain juga sempat merasa bahwa jika mereka terus-menerus mengonsumsi narkoba maka ia tidak dapat menggapai mimpi dan cita-citanya. Lebih jauh, seluruh subjek mengalami gangguan kesehatan di mana mereka mengalami sakit-sakitan, menstruasi yang tidak lancar, hingga sakau. Meskipun begitu, pada akhirnya setiap subjek yang memilih untuk tidak lagi mengonsumsi narkoba saat ini berusaha untuk menjadi lebih baik dengan cara menghindari teman-teman yang membawa pengaruh negatif serta lebih fokus pada keluarga dan menggapai cita-cita.

Di samping itu, Cohen dan George (2010) berpendapat bahwa rasa bersalah berhubungan secara positif dan signifikan dengan religiusitas dan moral. Moral mencakup perasaan bersalah dan perasaan menyesal yang digambarkan sebagai ketidaknyamanan setelah melakukan pelanggaran. Hal ini juga terlihat pada masing-masing subjek di mana ia menyesal telah menyebabkan perekonomian keluarganya menjadi semakin menurun, terlebih pada subjek ketiga yang menjadi lebih tempramen hingga menyebabkan dirinya lepas kendali dan membunuh seseorang akibat dari konsumsi narkoba.

Lebih jauh, dari hasil penelitian juga ditemukan bahwa tiga dari empat subjek mulai menggunakan narkoba ketika menginjak usia remaja. Di sisi lain, penggunaan narkoba merupakan salah satu hal yang dianggap menyimpang dari norma hukum dan sosial (Sumara, dkk., 2017). Jika pengguna narkoba tersebut merupakan seseorang yang masih tergolong di usia remaja, maka perilaku tersebut termasuk sebagai bentuk kenakalan remaja (Amelia \& Rachmy, 2017).

Santrock (2002) menyatakan bahwa kenakalan remaja merupakan suatu perbuatan melanggar hukum yang dilakukan oleh remaja, di mana jika perbuatan tersebut dilakukan oleh orang dewasa maka hal tersebut merupakan bagian dari kejahatan. Lebih jauh, perilaku kenakalan remaja dapat disebabkan oleh kurangnya kontrol diri pada remaja (Santrock, 2007). Dalam hal ini, kontrol diri merupakan kemampuan individu dalam memodifikasi perilaku, mengelola informasi yang tidak diinginkan, serta kemampuan dalam pengambilan keputusan terkait tindakan apa yang akan diambil sesuai dengan keyakinannya (Averil, 1973; Fidiana, 2014). Berdasarkan hal tersebut, remaja yang tidak mampu mempelajari tingkah laku sesuai dengan norma atau hukum yang berlaku, serta tidak dapat mengembangkan kontrol dirinya untuk dapat bertindak sesuai dengan pengetahuannya, maka akan cenderung melakukan kenakalan.

Hal serupa juga terjadi pada seluruh subjek, di mana keempat subjek dalam proses bergaulnya memiliki kontrol diri yang lemah sehingga membuat mereka terjerumus dan menjadi pengguna narkoba. Adapun seluruh subjek dalam penelitian ini mengaku mengenal narkoba melalui saudara atau teman sebaya. Ajakan dari teman sebaya yang dikenal subjek sudah cukup lama tentunya membuat subjek menjadi hilang kendali dan mudah percaya dengan ajakannya. Meskipun begitu, seiring berjalannya waktu subjek yang mulai beranjak dewasa mulai mampu untuk mengendalikan kontrol dirinya terbukti dari hasil wawancara yang menyatakan bahwa subjek merasa apa yang telah dilakukannya tidak memberikan dampak positif baik bagi dirinya sendiri maupun bagi orang-orang di sekitar. Dalam hal ini, subjek telah mampu mengembangkan kemampuannya dalam kontrol diri. Sebagaimana Fidiana (2014) menyebutkan bahwa adanya kontrol diri dapat mengendalikan setiap perilaku menuju ke arah yang lebih positif dan menghindari munculnya perilaku kenakalan.

Hadirnya kontrol diri pada subjek ini tentunya dapat mengarahkan mereka kepada tindakantindakan positif. salah satunya adalah dengan mengakui bahwa dirinya pernah melakukan sebuah kesalahan. Sebagaimana Averil (dalam Fidiana, 2014) menyebutkan bahwa adanya kontrol diri dapat membantu individu dalam memodifikasi perilaku. Dalam hal ini, subjek telah berusaha untuk mengevaluasi perilaku negatif dan kemudian memperbaikinya dengan tidak lagi terjerumus pada kesalahan yang sama. Berdasarkan hal tersebut, subjek sedang berada pada fase merasa bersalah telah berperilaku melawan hukum. Sebagaimana Cohen, dkk., (2011) menyatakan bahwa terdapat dua karakteristik khusus ketika individu merasa bersalah yaitu evaluasi perilaku negatif dan memperbaiki suatu tindakan.

Hal tersebut yang juga terjadi pada keempat subjek, di mana pada subjek pertama dan keempat merasa menyesal pernah mengonsumsi narkoba. Lebih dari itu, kedua subjek tersebut saat ini sudah menerima masa lalunya dan ingin berubah menjadi pribadi yang lebih baik lagi dimulai dengan lebih selektif dalam berteman. Sedangkan pada subjek kedua dan ketiga merasa menyesal telah mengonsumsi narkoba lantaran hal itu memberikan dampak negative bagi diri mereka. 


\section{Kesimpulan}

Narkoba telah disalahgunakan orang di berbagai kalangan dan usia, Efek yang ditimbulkan dari pemakaiannya yaitu membuat pemakainya mampu melupakan permasalahan dan membuat terbang hingga akhirnya menimbulkan ketagihan. Namun apabila sakau, pengguna narkoba akan merasakan dampak buruknya sehingga membuat penggunanya melakukan berbagai tindakan kejahatan agar mampu mendapatkan barang haram tersebut. Tidak sedikit dari pengguna yang akhirnya berhenti menggunakan narkoba karena efek sampingnya.

Perasaan bersalah dan beban pikiran juga ikut menyelimuti mantan pengguna narkoba. Sebagaimana hasil penelitian ini menunjukkan berbagai bentuk rasa bersalah dari para pengguna meliputi perasaan tertekan, menyalahkan diri sindiri dan meminta maaf kepada pihak-pihak yang dirugikan, menarik diri dari lingkungan, hingga memutuskan untuk mendekatkan diri dengan Allah.

\section{Daftar Pustaka}

Al-Mighwar, M. (2011). Psikologi Remaja. Bandung: Pustaka Setia.

Cohen, Taya R. (2010). Moral Emotions \& Unethical Bargaining The Differential effects of Emphaty and perspective Taking in Deterring Deceitful Negotiation.

Cohen, Taya R., Scott T. Wolf, A. T. Panter, \& Chester A. Insko. (2011). Introducing the GASP Scale: A New Measure of Guilt and Shame Proneness. Journal of Personality and Social Psychology, 100 (5), 947-966.

Coleman, Vernon. (1985). Rasa Salah: Mengapa Terjadi, Bagaimana Mengatasinya. Jakarta: Arcan Press.

Eisenberg, N. (2000). Emotion, Regulation, and Moral Development. Annual Review of Psychology. 51(1), 665.

Erikson, Erik. (1989). Identitas dan Siklus Hidup Manusia. Jakarta: Gramedia.

Feist, Jess, \& Gregory J. Feist. (2010). Teori Kepribadian. Jakarta: Salemba Humanika.

Ferguson, T. J., \& Stegge, H. (1998). Measuring guilt in children: A rose by any other name still has thorns. In J. Bybee (Ed.). Guilt and children. 19-74. San Diego: Academic Press.

Fidiana, Naili Rohmawati. (2014). Hubungan Antara Kontrol Diri Dengan Perilaku Delinquency Pada Remaja di SMP Bhakti Turen Malang. Universitas Islam Negeri Maulana Malik Ibrahim Malang Fakultas Psikologi.

Hurlock, Elizabeth B. (1997). Psikologi Perkembangan: Suatu Pendekatan Sepanjang Rentang Kehidupan. Jakarta: Erlangga.

Jahja, Yudrik. (2011). Psikologi Perkembangan. Jakarta: Kencana.

Mental Illness Fellowship Victoria. (2008). Understanding Guilt. Diakses melalui http://www.sharc.org.au/wp-content/uploads/2017/06/Understanding-guilt-Wellways.pdf diakses pada 30/12/2019.

Newman, Barbara M., \& Philip R. Newman. (2012). Life-span Development: A Psychosocial Approach. Wadsworth Cengage Learning.

Nurmaya, Alya. (2016). Penyalahgunaan NAPZA di Kalangan Remaja (Studi Kasus pada 2 Siswa di MAN 2 Kota Bima). Jurnal Psikologi Pendidikan \& Konseling, 2 (1) 26-32.

Pratiwi, Yanna Anggraini. (2018). Rasa Bersalah Pada Remaja Pelku Klitih. Jurnal Riset Mahasiswa Bimbingan dan Konseling, 4 (7) 298-308.

PUSLITDATIN. (12 Agustus 2019). Penggunaan Narkotika Kalangan Remaja Meningkat [online]. https://bnn.go.id/penggunaan-narkotika-kalangan-remaja-meningkat/ diakses pada 29/12/2019.

Santrock, John W. (2002). Masalah Belajar dan Inovasi Pembelajaran. Bandung: Refika Aditama.

Santrock, John W. (2007). Remaja Jilid 2. Jakarta: Erlangga.

Sumara, Dadan, Sahadi Humaedi, \& Meilanny B. Santoso. (2017). Kenakalan Remaja dan Penanganannya. Jurnal Penelitian \& PPM, 4 (2) 129-389.

Syifaunnufush, Amelia Dwi \& R. Rachmy Diana. (2017). Kecenderungan Kenakalan Remaja Ditinjau Dari Kekuatan Karakter DanPersepsi Komunikasi Empatik Orangtua. Jurnal Psikologi Integratif, 5 (1) 47-68. 